\title{
PRRS IN THE NOZOPROFILE OF INFECTIOUS DISEASES IN PIGS IN CHORNUHYNSKY DISTRICT OF POLTAVA REGION
}

\author{
V.O. Golovko, R.V. Severin, R.V. Voitenko, V.A. Kochmarski, I.M. Ivanchenko, A.M. Gontar, M.V. Kuzmenko \\ Kharkiv State Zooveterinary Academy, Kharkiv, Ukraine
}

Article info

Received 25.03.2019

Received in revised form

08.04.2019

Accepted 15.04.2019

Kharkiv State Zooveterinary

Academy, Kharkiv, Ukraine

Academic Str. 1. Malaya

Danilovka, Dergachi district, Kharkov region, Ukraine,

62341

E-mail:

Vaselek2006@ukr.net
Golovko, V.O., Severin, R.V., Voitenko, R.V., Kochmarski, V.A., Ivanchenko, I.M., Gontar, A.M., \& Kuzmenko, M.V. (2019). PRRS in the nozoprofile of infectious diseases in pigs in Chornuhynsky district of Poltava region. Veterinary science,technologies of animal husbandry and nature management, 3, 243-249. doi: 10.31890/vttp.2019.03.33.

Infectious pathology of pigs in the region is represented mainly bacterial diseases $(52,8 \%$ of the total infectious diseases). However, the bacteria, as is usually secondary pathogens to cause clinical picture against viral disease. Among the latter occupies a special place reproductive and respiratory syndrome, characterized by obstetric and gynecological diseases in sows and respiratory problems in piglets.

More and more reports have appeared in the world literature of the recent years, indicating the widespread distribution of the porcine reproductive and respiratory syndrome in North America and Europe. Currently, two types of virus are identified from pigs - the North American and European. PRRS is widespread also in Ukraine. The incidence in individual farms may exceed 55\%, while the mortality observed in 2-6-month-old pigs varies from 1 to $25 \%$. A serious decline in the growth and development of piglets is present.

Viral diseases are one of the main causes of reproductive disorders in sows. The reproductive and respiratory syndrome (PRRS) is one of such diseases. That is why it is important to quickly and reliably determine the cause of the diseases in animals.

A successful prevention of viral infections, which forms the basis of etiology of reproductive disorders, is dependent on an in-depth study of the nature of the viruses, antigenic and biological properties of their components, mechanisms of their relationship with cells, pathogenesis, factors of specific and nonspecific immunity as well as possible associations.

The purpose of our research was a detailed study of the epizootic situation regarding the reproductive and respiratory syndrome of pigs in farms of different forms of ownership in the Chernukhinsky district of the Poltava region.

In order to determine the role and place of PRRS in the infectious pathology of pigs in the conditions of the Chernukhinsky district of the Poltava region, we have examined the nozological profile, density, geographical distribution and annual dynamics of infectious diseases in 
pigs. The diagnostics of PRRS was performed using a test system for detecting a pathogenic RNA in a pathological material using a polymerase chain reaction method (PCR) with electrophoretic detection of agarose gel amplification products. In addition, we determined presence of specific antibodies to the PRRS agent in blood serum using the IFA method.

The results of our research showed that the ratio of viral to bacterial diseases in pigs in the Poltava region, taking into account associative manifestations of infectious pathology, was within the range of 1:1.

PRRS ranks first and accounts for 26,2\% of the cases. In addition, the mycoplasmosis accounts for $25,1 \%$, transmissible gastroenteritis of swine for $22,1 \%$, circovirus infection for $17,6 \%$, colibacillosis for $11.3 \%$, PVIP - 9,3\%, pasteurellosis - 7,3\%, enzootic pneumonia for $6,8 \%$.

In order to ensure the epizootic welfare of pigs in Chornuhynsky district, an ongoing monitoring of PRRS as well as prompt and reliable revealing of the cause of disease in animals should be conducted.

Key words: PRRS, diagnostics, virus, isolate.

\title{
РРСС В НОЗОПРОФИЛЕ ИНФЕКЦИОННОЙ ПАТОЛОГИИ СВИНЕЙ В ЧЕРНУХИНСКОМ РАЙОНЕ ПОЛТАВСКОЙ ОБЛАСТИ
}

\author{
В.О. Головко, Р.В. Северин, Р.В. Войтенко, В.А. Кочмарський, И.М. Иванченко, А.М. Гонтарь, М.В. Кузьменко \\ Харьковская государственная зооветеринарная академия, Харьков, Украина
}

В последние годы в мировой литературе появляются все больше сообщений, которые свидетельствуют о широком распространении репродуктивно-респираторного синдрома свиней на территории Северной Америки и Европы. В настоящее время от свиней выделены два типа вируса - североамериканского и европейский. РРСС широко распространен и на территории Украины. Заболеваемость в отдельных хозяйствах может превышать 55\%, однако смертность, которая наблюдается среди 2-6-месячных поросят, колеблется от 1 к 25\%. Отмечается резкая задержка роста и развития поросят.

Одной из главных причин репродуктивных расстройств у свиноматок можно назвать вирусные болезни, среди которых не последнее место занимает репродуктивно респираторный синдром (РРСС), поэтому очень важно своевременно, быстро и достоверно установить причину болезни животных.

Успешная профилактика вирусных инфекций, которые представляют основу этиологии репродуктивных расстройств, связана с более глубоким изучением природы вирусов, антигенных и биологических свойств их компонентов, механизмов взаимоотношений с клетками, патогенеза, фракторов специфического и неспецифического иммунитета, возможных ассоциаций.

Целью исследований было детальное изучение эпизоотической ситуации относительно репродуктивнореспираторного синдрома свиней в хозяйствах разной фрормы собственности Чернухинского района Полтавской области. Для определения роли и места РPCС в инфекционной патологии свиней в условиях Чернухинского района Полтавской области нами изучен нозологический профиль, удельный вес, географическое распространение и годовая динамика инфекционных заболеваний свиней. Диагностику РРСС проводили с помощью тест-системы для выявления РНК возбудителя в патологическом материале методом полимеразной цепной реакции (ПЦР) с электрофоретической детекцией продуктов амплифрикации в агаровом геле, а также определяли наличие специфических антител к возбудителю РРСС в сыворотке крови методом ИФА.

Результаты исследований показали, что соотношение вирусных и бактериальных заболеваний свиней в Полтавской области с учетом ассоциативных проявлений инфекционной патологии составляет в пределах 1:1. 
Распространенность РРСС занимает первое место и складывает 26,2\% случаев. Кроме этого, регистрируют микоплазмоз - 25,1\%, трансмиссивный гастроэнтерит - 22,1\%, цирковирусную инфрекцию - 17,6\%, колибактериоз - 11,3\%, ПВИС - 9,3\%, пастереллез - 7,3\%, энзоотическую пневмонию - 6,8\%.

С целью обеспечения эпизоотического благополучия свинопоголовья в Чернухинском районе Полтавской области необходимо вводить проведение постоянного эпизоотологического мониторинга РРСС; своевременно, быстро и достоверно устанавливать причину болезни животных.

Ключевые слова: РPCС, диагностика, вирус, изолят.

\title{
РРСС У НОЗОПРОФІЛІ ІНФЕКЦІЙНОЇ ПАТОЛОГІЇ СВИНЕЙ У ЧОРНУХИНСЬКОМУ РАЙОНІ ПОЛТАВСЬКІЙ ОБЛАСТІ
}

\author{
В.О. Головко, Р.В. Северин, Р.В. Войтенко, В.А. Кочмарський, \\ І.М. Іванченко, А.М. Гонтарь, М.В. Кузьменко
}

Харківська державна зооветеринарна академія, Харків, Україна

Інфекційна патологія свиней в Полтавській області представлена, в основному, бактерійними захворюваннями (52,8\% від загальної інфекційної патології). Проте бактерії $\epsilon$, як слід, вторинними патогенами, викликають клінічну картину на тлі вірусного захворювання. Серед останніх особливе місце займає репродуктивнореспіраторний синдром свиней, який характеризується акушерсько-гінекологічною патологією у свиноматок $і$ респіраторними проблемами у поросят групи дорощення і відгодівлі. За поширеностю інфрекцій свиней в Полтавській області РРСС займає третє місце $(11,4 \%)$.

Ключові слова: РPCС, діагностика, вірус, ізолят.

\section{Вступ}

Серед захворювань свиней, причиною яких $є$ віруси, слід назвати паровірусний ентерит, РРСС, цирковірусну інфекцію, трансмісивний гастроентерит і ротавірусну інфекція. Останніми роками у світовій літературі з'являється все більше повідомлень, що свідчать про широке поширення репродуктивнореспіраторного синдрому свиней на території Північної Америки і Європи. Нині від свиней виділено два типи вірусу - північноамериканський і європейський (Ben eld, D.A. et al.,1999;. Christopher-Hennings, Faaberg, \& Murtaugh, 2002; De Paz, Vega, Duran, \& Angulo, 2015; Dietze, Pinto, Wainwright, \& Hamilton, 2011). PPCC широко поширений і на території України. Захворюваність в окремих господарствах може перевищувати 55\%, проте смертність, яка спостерігається серед 2-6-місячних поросят, коливається від 1 до 25\%. Відзначається різка затримка росту і розвитку поросят (Zelenuхa, \& Sidorchuk, 2012; Velasova, Alarcon, Williamson \& Wieland, 2012).

Актуальність теми. Одним із найбільш розповсюджених напрямків розвитку сільського господарства в Україні $€$ свинарство і проблема відновлювання - одна з найважливіших. На сьогодні однією з головних причин репродуктивних розладів у свиноматок можна назвати вірусні хвороби, серед яких не останнє місце займає репродуктивно респіраторний синдром (РРСС), тому дуже важливо своєчасно, швидко та достовірно встановити причину хвороби тварин (Orljankin, Aliper, \& Nepoklonov, 2005; Kukushkin, \& Bajbikov, 2005).

Аналіз останніх досліджень і публікацій. Над з'ясуванням етіології та епізоотології респіраторних хвороб свиней працювали: А. П. Герілович, Є. В. Смолянінова, В. І. Болотін, А. І. Бузун, О. В. Дунаєва.

Репродуктивні розлади $€$ надзвичайно поліетіологічними. Факторами, що їх зумовлюють $€$ погані умови утримання, низький рівень якості кормів, неякісна профілактика та лікування інфекційних та інвазійних хвороб. Успішна профрілактика вірусних інфекцій, що складають основу етіології репродуктивних розладів, пов'язана з більш глибоким вивченням природи вірусів, антигенних і біологічних властивостей їх компонентів, механізмів взаємовідносин 3 клітинами, патогенезу, фракторів специфічного й неспецифічного імунітету, можливих 
асоціацій (Kleiboeker, 2005; Sytiuk, Masiuk, \& Kokariev, 2016; Pejsak, 2008).

Метою наших досліджень було детальне вивчення епізоотичної ситуації щодо репродуктивнореспіраторного синдрому свиней у господарствах різної форми власності Чорнухинського району Полтавській області.

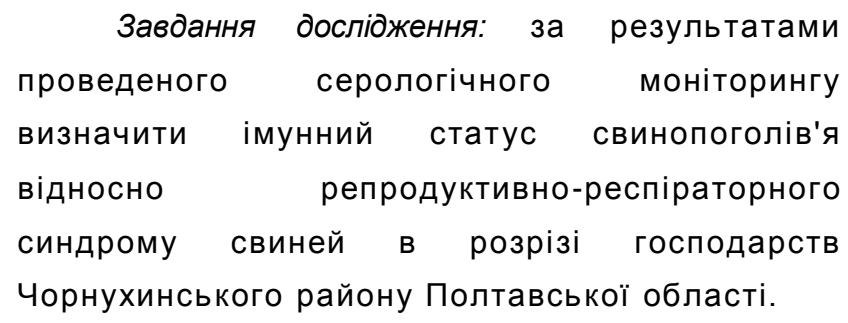

\section{Матеріали і методи досліджень}

Роботу виконували з 2016 до 2019 рр. на базі кафредри епізоотології та ветеринарного менеджменту ХДЗВА, а також в господарствах Полтавської області. Для визначення ролі і місця РPCC в інфекційній патології свиней в умовах Чорнухинського району Полтавської області нами вивчений нозологічний профіль, питома вага, географрічне поширення і річна динаміка інфекційних захворювань свиней. Діагностику РPCС проводили за допомогою тест-системи для виявлення РНК збудника в патологічному матеріалі методом полімеразної ланцюгової реакції (ПЛР) 3 електрофоретичною детекцією продуктів ампліфікації в агарозному гелі, а також визначали наявність специфічних антитіл до збудника ензоотичної пневмонії в сироватці крові методом ІФА.

\section{Результати та їх обговорення}

За період з 2016 по 2019 рр. в господарствах різної форми власності Чорнухинського району Полтавської області огляду піддано 5211 свиней. 3 них у 20,2\% виявлена інфекційна патологія. За піддослідними тваринами було встановлено постійне клінічне спостереження, при цьому враховували відсоток захворюваності, одужання і загибелі. Щодня проводили клінічне обстеження поросят, а лабораторні дослідження проводили при первинному і повторному оглядах та після одужання.

Для вивчення епізоотичної ситуації щодо РРСС було проведено обстеження поголів'я свиней в шести господарствах різної форми власності Чорнухинського району Полтавської області, проаналізовані результати лабораторних досліджень .

Полтавська область $€$ зоною із складною епізоотичною ситуацією щодо інфекційних хвороб. У господарствах регіону щорічно хворіють інфекційними хворобами від 35 до 90\% поросят. Із загальної кількості поросят , що загинули в 2016-2019 роках, загибель їх від респіраторних хвороб склала $42 \%$.

Ми провели ретроспективний аналіз рівня захворюваності свиней інфекційними хворобами в Полтавській області за період 2016-2019 рр. Вивчали питому вагу РРСС в порівняльному аспекті і в динаміці. В результаті виділені наступні нозологічні одиниці (рис. 1).

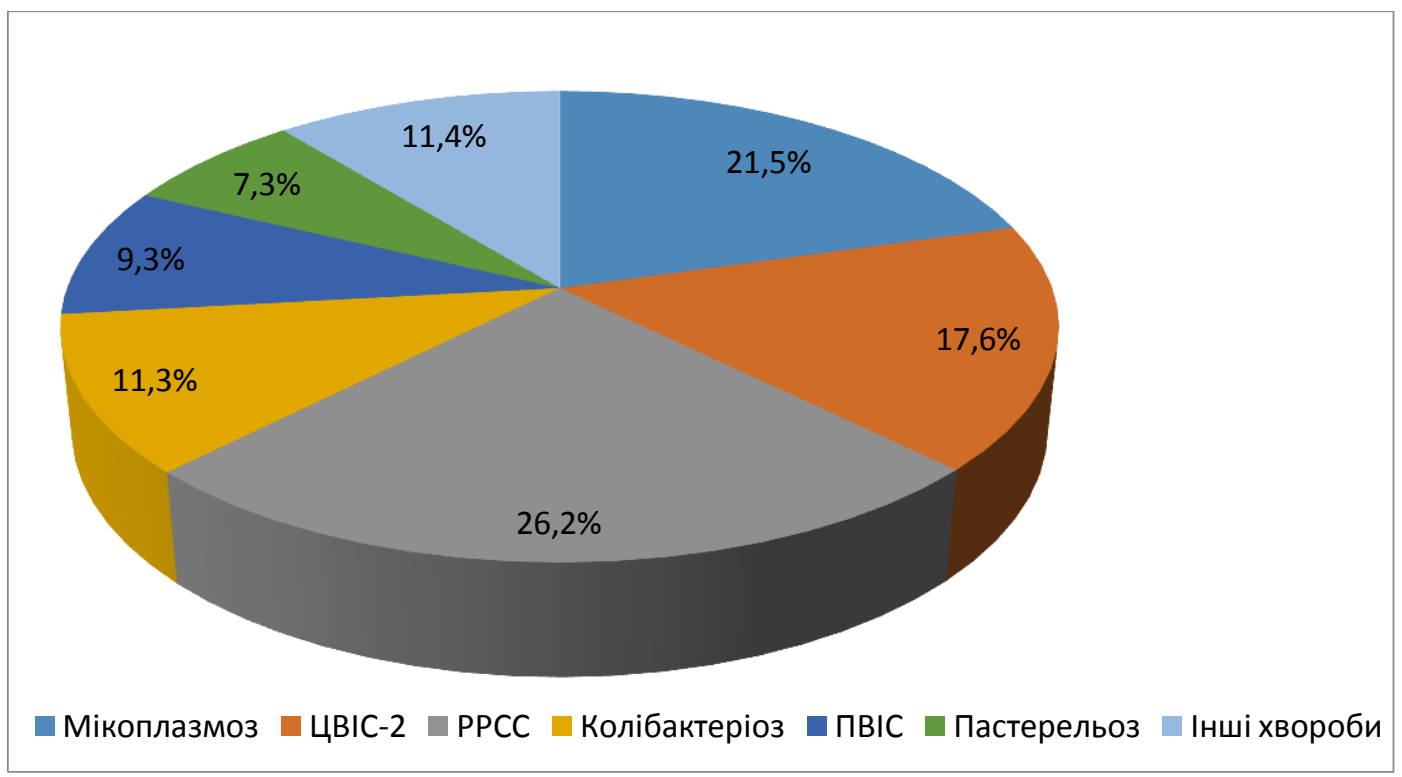

Рис. 1. Нозологічний профріль інфрекційної патології свиней в Полтавській області в 2016-2019 p

За 4 роки (2016-2019рр.) інфекційна патологія свиней представлена, в основному, бактерійними захворюваннями. Найчастіше за цей період реєстрували мікоплазмоз - 25,1 \%, цирковірусну 
інфекцію - 17,6 \%, РРСС - 26,2 \%, колібактеріоз - 11,3

захворювань припадає $11,4 \%$.

\%, ПВІС - 9,3 \%, пастерельоз - 7,3 \%. На долю інших

Таблиця 1

Нозологічний профіль інфекційної патології свиней в Полтавській області за 2016-2019 рр.

\begin{tabular}{|c|c|c|c|}
\hline Нозологічна одиниця & $\begin{array}{c}\text { Досліджено } \\
\text { тварин }\end{array}$ & Захворіло & $\%$ \\
\hline Мікоплазмоз & 155 & 39 & $25,1 \%$ \\
\hline ЦВІС-2 & 142 & 25 & $17,6 \%$ \\
\hline PPCC & 187 & 49 & $26,2 \%$ \\
\hline Колібактеріоз & 343 & 39 & $11,3 \%$ \\
\hline$\Pi \mathrm{BIC}$ & 395 & 37 & $9,3 \%$ \\
\hline Пастерельоз & 925 & 68 & $7,3 \%$ \\
\hline Ензоотична пневмонія & 88 & 6 & $6,8 \%$ \\
\hline Бешиха & 498 & 30 & $6,0 \%$ \\
\hline Сальмонельоз & 1623 & 81 & $4,9 \%$ \\
\hline Трансмісивний ГЕ & 152 & 34 & $22,2 \%$ \\
\hline Інші бак. дослідження & 88 & 3 & $3,4 \%$ \\
\hline Псевдомоноз & 67 & 1 & $1,5 \%$ \\
\hline Гемофрільозний полісерозит & 164 & 4 & $2,4 \%$ \\
\hline Стрептококкоз & 87 & 3 & $3,4 \%$ \\
\hline Ротавірусна інфекція & 314 & 2 & $0,6 \%$ \\
\hline Ауєскі хвороба & 3 & 0 & $0,01 \%$ \\
\hline Всього & 5211 & 412 & $100 \%$ \\
\hline
\end{tabular}

Пік захворюваності свиней РРСС доводиться на кінець зими - початок весни (рис. 2), що пов'язано зі зниженням імунного статусу свиней на фоні гіповітамонозів, зниження якості комбікормів в зимововесняний період.

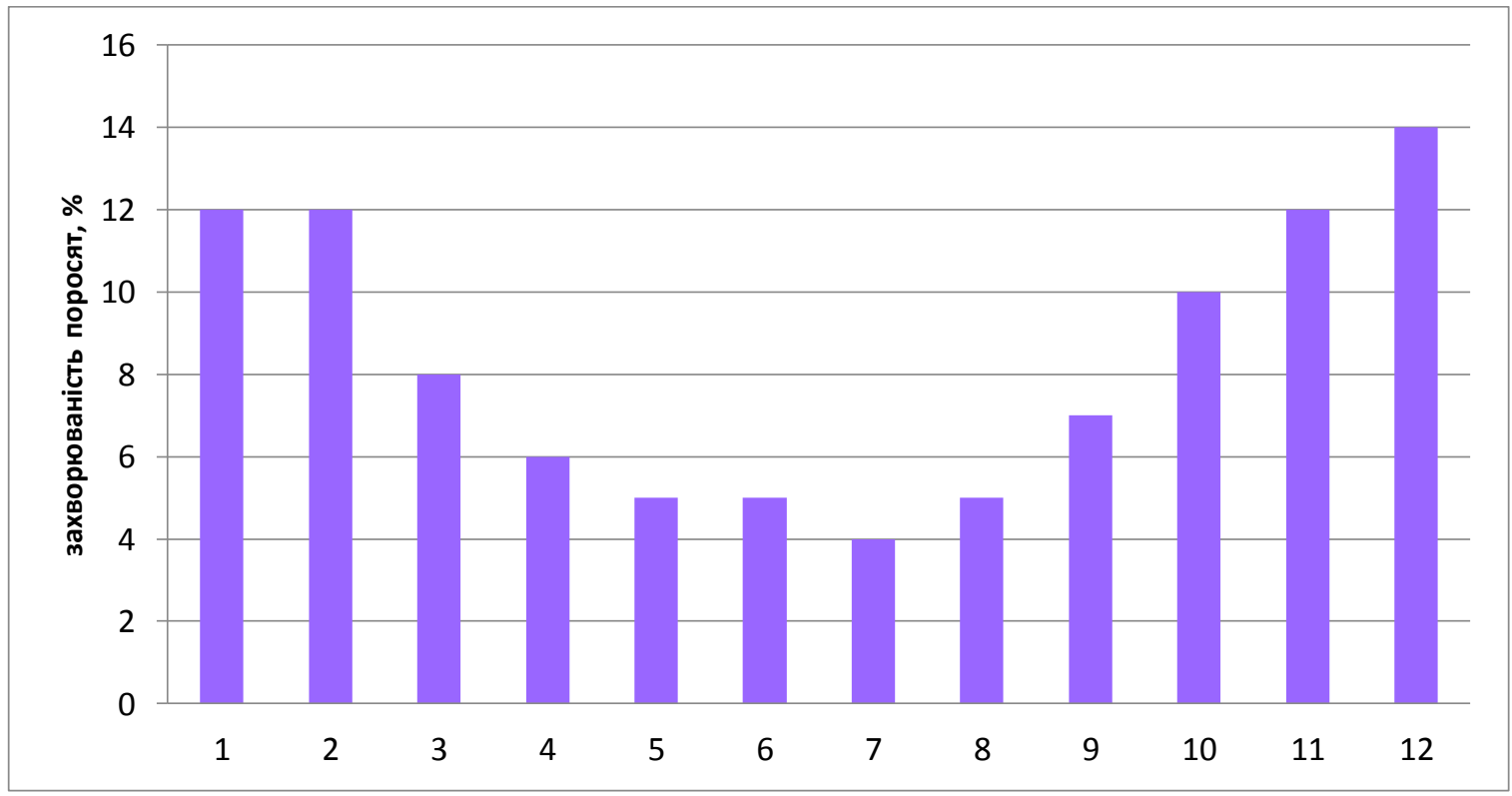

Рис. 2. Динаміка захворюваності поросят РРСС в Полтавській області 
Таку динаміку можна пояснити і різкими змінами кліматичних чинників, які призводять до маніфестації інфекції за наявності збудника в організмі. Крім того, ми провели аналіз поширення асоціативних хвороб у свиней при РРСС в господарствах різної фрорми власності Полтавської області в 2019 р. РРСС як моноінфекція не реєструється, їі збудник обов'язково виявляється у асоціаціях з іншими інфекційними агентами: парвовірусом свиней (12 \%), мікоплазмозом (24\%), ЦВІС (32 \%), 3 пастерельозом (12 \%), стрептококозом (8\%), вірусом хвороби Ауєскі (10,5 \%), з гемофрільозом (5,5\%), ензоотичною пневмонією (15\%). Відмінною особливістю РPCС є те, що частіше за все хвороба не протікає у вигляді моноінфекції, а в асоціації 3 іншими інфекціями, що робить більш різноманітну картину хвороби. При проведенні лабораторного дослідження методом ПЛР, найчастіше збудника РРСС виділяли у поросят 1-8 тижневого віку, що складало 46\%,у віці 8-15 тижнів-34\%, на вік 16-24 тижні припадало 19,8\%. Пік сероконверсії доводився на вік 818 тижнів.

Динаміка захворюваності, смертності і летальності при РPCC в Чорнухинському районі Полтавської області була проаналізована за 2018-2019 роки (таблиця 2).

Таблиця 2

Динаміки захворюваності, смертності і летальності при РРСС

\begin{tabular}{|c|c|c|c|c|c|c|}
\hline Рік & $\begin{array}{c}\text { Сприйнятливі } \\
\text { тварини, гол }\end{array}$ & $\begin{array}{c}\text { Захворіло, } \\
\text { гол. }\end{array}$ & Загинуло & $\begin{array}{c}\text { Захворюваність на } \\
1000 \text { голів }\end{array}$ & $\begin{array}{c}\text { Смертність на } \\
1000 \text { голів }\end{array}$ & Летальність, \% \\
\hline 2018 & 1450 & 950 & 352 & 655,1 & 242,7 & $37,0 \%$ \\
\hline 2019 & 945 & 842 & 345 & 890,1 & 365,0 & $40,9 \%$ \\
\hline
\end{tabular}

У 2018 році смертність РРСС склала 242,7 голів на 1000 сприйнятливих свиней при летальності 37,0\%. У 2019 році ці показники істотно не змінилися смертність склала 365,0 голів на 1000 сприйнятливих тварин, а летальність - 40,9\%.

\section{Висновки}

1. Співвідношення вірусних i бактерійних захворювань свиней в Полтавській області 3 урахуванням асоціативних проявів інфекційної патології складає 1:1.

2. За поширеностю інфеекцій свиней РPСС займає перше місце 26,2\%. Окрім цього, реєструють мікоплазмоз - 25,1\%, трансмісивний гастроентерит $22,1 \%$, цирковірусну інфекцію - 17,6\%, колібактеріоз $11,3 \%$, ПВІС - 9,3\%, пастерельоз - 7,3\%, ензоотичну пневмонію - 6,8\%.

3. Для забезпечення благополуччя свинопоголів'я в Чорнухинському районі необхідно проведення постійного епізоотологічного моніторингу PРCC; своєчасно, швидко та достовірно встановлювати причину хвороби тварин.

Перспективи подальших досліджень. Проведення поглиблених досліджень поширення вірусів, а також їх асоціацій, що дасть змогу детальніше вивчити етіологію та епізоотологію захворювання.

\section{References}

Ben eld, D.A., Collins, J.E., Dee, S.A., Halbur, P.G., Joo, H.S., Lager, K.M. ... Zimmerman, J.J. (1999). Porcine reproductive and respiratory syndrome. Diseases of Swine, 18, 201-232

Chen, C., Fan, W., Jia, X., Li, J., Bi, Y., \& Liu, W. (2013). Development of a recombinant N-Gp5c fusion proteinbased ELISA for detection of antibodies to porcine reproductive and respiratory syndrome virus. $J$ VirolMeth, 189, 213-220.

Christopher-Hennings, J., Faaberg, K.S., \& Murtaugh, M.P. (2002). Porcine reproductive and respiratory syndrome (PRRS) diagnostics: Interpretation and limitations. Swine Health. Prod, 10(5), 213-218.

De Paz, X., Vega, D., Duran, C. O., \& Angulo, J. (2015). PRRS prevalence in Europe: Perception of the pig veterinary practitioners. Boehringer Ingelheim. Animal Health. Germany: ESPHM.

Dietze, K., Pinto, J., Wainwright, S., \& Hamilton, C. (2011). Porcine reproductive and respiratory syndrome (PRRS): virulence jumps and persistent circulation in 
Southeast Asia, 5, 8.

Ferrin, N.H, Fang, Y, Johnson, C.R, Murtaugh, M.P., Polson, D.D., Torremorell, M. ... Nelson, E.A. (2004). Validation of a blocking enzyme-linked immunosorbent assay for detection of antibodies against porcine reproductive and respiratory syndrome virus. Clin. Diagn. Lab. Immunol, 11, 503514.

Grebennikova, T. V., Zaberezhnyj, A. D., \& Nepoklonov, E. A. (2005). Sredstva laboratornoj diagnostiki reproduktivnogo i respiratornogo sindroma svinej [Facilitie laboratory diagnostics of porcine reproductive and respiratory syndrome]. Veterinarija, 10, 24-26.

Kleiboeker, S. B. (2005). Simultaneous detection of North American and European porcine reproductive and respiratory syndrome virus using real-time quantitative reverse transcriptase-PCR. J Vet Diagn Invest, 17, 165-170.

Kukushkin, C.A., \& Bajbikov, T.Z. (2005). Osobennosti specificheskoj profilaktiki reproduktivnorespiratornogo sindroma i parvovirusnoj infekcii svinej. Veterinariya i kormlenie, 4, 15-18.

Orljankin, B. G., Aliper, T. I., \& Nepoklonov, E. A. (2005). Infektsionnye respiratornye bolezni svinej [Infectious respiratory disease of swine]. Veterinarija, 11, 3-6.

Pejsak, Z. (2008). Bolezni svinej [Diseases of Swine]. Brest: Brestskaja tipografija.

Plans for control and elimination RRSS in Europe. Retrieved from https://www.pig333.ru/prrs/

Sytiuk, M.P., Masiuk, D.M., Kokariev, \& A.V. (2016). Analiz rezultativ serolohichnykh doslidzhen sviiskykh svynei shchodo reproduktyvno-respiratornoho syndromu $v$ Ukraini za 2013-2015 roky [Analysis of serological tests of domestic pigs of porcine reproductive and respiratory syndrome in Ukraine for 2013-2015 years]. Veterynarna medytsyna, 102, 180-185.

Velasova, M., Alarcon, P., Williamson, S., \& Wieland, B (2012). Risk factors for porcine reproductive and respiratory syndrome virus infection and resulting challenges for effective disease surveillance. $B M C$ Vet Res, 8, 184.

Wills, R. W., Zimmerman, J., \& Yoon, K. (1997). Porcine reproductive and respiratory syndrome virus: routes of excretion. Vet. Microbiol. 57, 69-81.

Zelenuxa, E.A., \& Sidorchuk, A.A. (2012). Problema kompleksnogo respiratornogo sindroma $\mathrm{V}$ promy`shlennom svinovodstve. Rossijskij veterinarny $j$ zhurnal, 2, 22-25. 